\title{
Western Image Of The Orient And Oriental In Agatha Christie's Death On The Nile: A Postcolonial Reading
}

\section{Agatha Christie'nin Nil'de Ölüm Başlıklı Romanında Doğu ve Doğulunun Batılı İmgeleri: Postkolonyal Bir Okuma}

Mevlüde ZENGÍN ${ }^{1}$

Sie können sich nicht vertreten, sie müssen vertreten werden.

Karl Marx, Der 18te Brumaire des Louis Napoleon

\begin{abstract}
This paper attempts to read Agatha Christie's Death on the Nile (1937), a Hercule Poirot detective novel from a postcolonial stand in general but in particular it seeks traces of Orientalism in it. Expertly plotted and set in Egypt, an exotic background, Death on the Nile is analyzed in this study, through Edward W. Said's critique of Orientalism, to detect the novel's projection of the Orient and oriental. Orientalism is defined by Edward Said in his groundbreaking book Orientalism (1978) as a scholarly discipline involving the negative portrayal of the East and eastern people, values and culture by westerners and as western construction of the Orient in occidental discourse through western perspective. Composed of two sections the essay begins with a brief introduction to postcolonial criticism and the critique of Orientalism. Next Death on the Nile is analyzed in the light of the criticism of Orientalism in the second section. The projection of the Orient and oriental people, places, values, concepts and so forth detected in the novel are presented in two subsections of this part. The study concludes that Death on the Nile being a detective novel has an orientalist quality when it comes to the reflection of the Orient and oriental though Christie does not foreground this quality of the novel. Another conclusion reached at the end of this study is that for Christie, the Queen of detective fiction has been considered to be a best-selling novelist of all time, her novel, Death on the Nile with its orientalist attitude to the East and easterner, must have contributed to the construction of a negative and false image of the Orient in western mind and discourse.
\end{abstract}

Key Words: Death on the Nile, Agatha Christie, Edward Said, Orientalism, Western Image of the Orient, the Projection of the Orient

\footnotetext{
1 Asst. Prof., Cumhuriyet University, Faculty of Letters, The Department of English Language and Literature, e-mail: mzengin@cumhuriyet.edu.tr
} 
Özet

Bu çalışma Agatha Christie'nin bir Hercule Poirot dedektif romanı olan Nil'de Ölüm (1937) başlıklı eserini genelde postkolonyal eleştiri doğrultusunda okumayı hedeflerken özde romandaki oryantalist izleri araştırmaktadır. Çalışmada ustaca kurgulanan ve egzotik arka plan olarak Mısır'ı alan Nil'de Ölüm, Edward W. Said'in Oryantalizm eleştirisi bağlamında romandaki Doğu ve doğuya ait imgeleri yansıtma biçimini belirlemek üzere analiz edilecektir. Oryantalizm, Edward Said'in çığır açan kitabı Orientalism'de (Oryantalizm/Şarkiyatçılık) Doğu ve doğu insanının, değerlerinin ve kültürünün olumsuz bir tasvirini içeren bir çalışma alanı olarak tanımlanır. Said'e göre Doğu Batının kendi perspektifi ile batı söylemlerindeki üretimidir. İki bölümden oluşan bu makale postkolonyal eleştiri ve dünyayı Batı ve Doğu olarak ikiye ayıran Avrupa merkezci bir görüş olan Oryantalizmin eleştirisine kısa bir giriş ile başlamaktadır. Daha sonra ikinci bölümde Nil'de Ölüm Oryantalizm eleştirisi ışı̆ında analiz edilmektedir. Bu bölümün iki alt bölümünde Doğu ve Doğu insanı, Doğuya ait yerler, değerler, kavramlar vb.nin romandaki yansıması çalışılmaktadır. Çalışma bir dedektif romanı Nil'de Ölüm başlıklı eserin Doğu ve doğuluyu yansıtma söz konusu olduğunda, Christie'nin romanın bu özelliklerini ön plana çıkarmamasına rağmen oryantalist bir tavır sergilediği görüşüyle son bulmaktadır. Çalışmada ortaya konan diğer bir sonuç ise dedektif romanının kraliçesi Christie'nin tüm zamanların en çok satan romancısı olmasından dolayı romanı Nil'de Ölüm'ün doğu ve doğuluya karşı oryantalist tavrıyla, Batılı zihinlerde ve söylemlerde negatif ve yanlış bir Doğu imgesi oluşturmaya katkıda bulunmuş olduğudur.

Anahtar Sözcükler: Nil'de Ölüm, Agatha Christie, Oryantalizm, Edward Said, Batının Doğu İmgesi, Doğunun Yansıması

\section{Introduction}

This paper argues that Agatha Christie's Death on the Nile (1937), a Hercule Poirot detective novel offers an analysis from a postcolonial perspective because it includes traces of Orientalism. So the essential purpose of this study is to analyze Death on the Nile by means of Edward W. Said's critique of Orientalism and to detect the novel's projection of the Orient and oriental. Orientalism is defined by Edward Said in his groundbreaking book Orientalism (1978) as a scholarly discipline involving the negative and false portrayal of the East and Eastern people, values and culture by westerners and as western construction of the Orient in occidental discourse through western perspective. Therefore, the Orient is a discursive production of the West. Said also argues that the West constructed the East as an antithesis of the West, as the "Other". The study will first introduce the postcolonial criticism and Said's view of and critique of Orientalism, a Eurocentric belief which divided the world as the Occident and the Orient. For Said this was an artificial and imaginary division that caused and strengthened the superiority of the European over the nonEuropean. Said's attacks on western perspective employed in western discourses reflecting the Orient and oriental values will be touched upon in the first part of the study as well. Then Death on the Nile will be dealt with to indicate how Christie portrayed the Orient and oriental in the novel. The second part of the study has been organized in two sections. In the first subdivision, Christie's depiction of Egypt as an oriental place is studied, and in the second her portrayal of the oriental, including people, values, insights and concepts is 
presented. The study will conclude that bearing in mind that Christie is considered coming third in the rank of the world's authors whose books were and have been published most-widely behind Shakespeare's works and the Bible, her novel Death on the Nile must have contributed to the construction of a negative and false image of the Orient and oriental in western mind and discourse. However, it is questionable whether Christie made this contribution consciously or unconsciously, in other words, on purpose or not because we cannot claim that to draw a negative image of the Orient and oriental was the writer's first aim in writing detective fiction and in her putting the oriental images in her novels whose setting is at least oriental. Shortly, the argument about the reason for Christie's orientalist attitude in her novel is out of the scope of this study and therefore, in the context of this study, my explanation about the reason for her orientalist approach toward the East and easterner cannot go beyond a prediction and deduction that she must have had prejudices and strong opinions about the East and easterners.

\section{Postcolonialism and Orientalism}

In the field of literary disciplines postcolonial theory and criticism concerning with the decentralization of western culture and its values devotes much effort to the critique of the ideologies of colonial domination such as Eurocentrism and it is mostly based on the theories of such theoreticians as Aimé Césaire, Frantz Fanon, Edward Said, Albert Memmi and Homi Bhabha. But it is no purpose of this part to go into details of the theories formed by them; but rather give a synoptic view of postcolonial theory and its line with the critique of Orientalism to serve a general introduction to this paper. What collects these thinkers, authors and critics under the umbrella word postcolonialism is their attack on the dominance of western ideologies, the supremacy of western values, western modes of thought, western perceptions of the world, western division of the world into two as the East and West and westerners' imposing their own culture, language, religion and other values constituted by their western perspective on the eastern world and people. The mentioned theorists' rejections of the superiority of European countries and America over the Eastern world, of the global impact of European colonialism and the imperialistic deeds of both European countries and America have also been very influential on the postcolonial thought. Postcolonial studies also examining the impact of colonialism and imperialism on the nations colonized and formerly colonized delineate the colonial power and hegemony to which native people have been exposed and thus actually create an awareness of what the colonial man has done to the colonized throughout centuries and how the Western world has exploited the Eastern world in every respect. The negative effects of colonization on both the colonizer and the colonized, one of the most bitter examples to which is, for instance, the dehumanization of man, have also been rendered in works whether be literary or non-literary, whether in fiction or non-fiction and written either in the colonial period, if not many, and during the decolonization process. By means of numberless works written in the postcolonial period in the wake of decolonization one can observe that one of 
the essential aims of postcolonial literature is to react against or write back to the works appreciating and legitimizing the acts of colonialism and imperialism by means of either transforming, distorting or deconstructing these works and resisting the ideologies pervasive in them and pervaded by them. Postcolonial texts not only foreground the cultural conflict but also put into question the connection between the colonizer and the colonized, in other words, between the central and peripheral or the European 'Self' and the racial 'Other'. Broadly speaking, the purpose of postcolonial criticism is to "describe the mechanisms of colonial power, to recover excluded or marginalized 'subaltern' voices, and to theorize the complexities of colonial and postcolonial identity, national belonging, and globalization" (Leitch, 2001, p. 25). Postcolonial literary criticism focuses mainly on the literatures produced in the historical and cultural contexts of colonial domination of the western powers most notably in Africa, Asia, and the Caribbean. One of the significant aims of the postcolonial theory is to analyze the literatures of both colonized and once colonized countries in order to explore "the complex interactions and antagonisms between native, indigenous, "precolonial" cultures and the imperial cultures imposed on them" (Leitch, 2001, p. 26).

One of the fundamental issues in postcolonial criticism concerns the representation of the East and eastern people by the West and through western perception in the western discourses about the East and the easterner. It was Edward W. Said (1935-2003) who problematized the objectivity of western representation of the Orient and oriental arguing that westerners having normative ideas on the Orient and its people constructed the image of an oriental world and people by means of their discourses. This image, for Said, did not match with the reality because it was imaginative and false. Orientalism is defined and attacked by Said in his groundbreaking book Orientalism first published in 1978. However, the animosity towards Orientalism and orientalists has some basics other than the one provided by Said. The first one is "L'orientalisme en crise," ("Orientalism in Crisis") written by Anouar Abdel-Malek and published first in Diogéne in 1963. Abdel-Malek (1924-2012) is an influential Egyptian author and thinker known to be the first critic of Orientalism and for his devotion to pan-Arabism. In his essay, first published in French, Abdel-Malek (2000) critically examines western attitudes towards the study of non-western societies. He also claims that immediately after the World War II, both the resurgence of the people of Asia, Africa and Latin America and also the victories gained by a range of national liberation movements paved the way for a new approach to the problem of understanding the Orient and oriental. Dealing with the Arab world and Egypt in particular, China and Southeast India, his study has a political vision on the deeds of orientalists, which Abdel-Malek calls the "traditional orientalism". The traditional orientalists, in Abdel-Malek's (2000) view, "was formed by an amalgam of university dons, businessmen, military men, colonial officials, missionaries, publicists and adventurers, whose only objective was to gather intelligence information in the area to be occupied, to penetrate consciousness of the people in order to better assure its enslavement 
to the European power" (p. 49). Therefore they served the imperialistic desires of the European countries. The general conception of the Orient and oriental is revealed in his work as in the following: "[Orientalists] consider the Orient and Orientals as an 'object of study, stamped with an otherness - as all that is different, whether it be 'subject' or 'object' - but of a constitutive otherness, of an essentialist character" (Abdel-Malek, 2000, p. 50). At the end of his work, Abdel-Malek concludes that Orientalism has a lack of objectivity and therefore it is far from being a scientific research. As a result, it can be said that AbdelMalek's assault on Orientalism sprang from his idea that Orientalism is itself an imperialistic deed. It complies with the general conviction that Orientalism was an instrument of imperialism which was designed to secure the colonization and enslavement of the Third-World countries.

The second critique of Orientalism before that of Said was provided by Abdul Latif Tibawi (1910-1981), a Palestinian historian and educationalist. It is "Critique of English-Speaking Orientalists". In his work Tibawi (2016) presents a historical analysis of the orientalist attitudes of the West toward the Islamic world and draws attention to the deep-seated hostility toward Islam and Arab nationalism of the Christian world. According to Tibawi (2016), Christian missionaries developing fixed, prejudiced ideas about Islam formed a close alliance with the orientalist academicians and the result was western domination on the Islamic nations and a cultural subordination of Muslims by Christians (pp. 5-9).

It is apparent that these two works explored Orientalism and provided the former critiques of Oientalism well before Said's seminal work Orientalism. Nevertheless, not until the publication of Said's book did these works and arguments involved in them receive attention in broader circles. So Orientalism, though Aram Veeser (2010) defines it, as an "epochal tome" (p. 83), is an epoch-making work. After the publication of Said's book "the study of race in relation to literature and culture widened enormously" (Bertens, 2002, p. 112). Owing to his Orientalism, "it has been often accepted as fact that Edward Said initiated the discourse of post-colonialism" (Ashcroft et. al. 2002, p. 198).

Said (1989) distinguishes between the three meanings of Orientalism. Firstly, it refers to a body of academic studies concerning the Orient and oriental peoples, cultures, languages, values and so on by means of teaching, writing about and researching them. "Oriental Studies" or "area studies" are used synonymously today to refer to this designation of Orientalism. Secondly, it refers to a style of thought based upon the idea of diversity between the Orient and the Occident. Thus, for Said, "a very large mass of writers, among whom are poets, novelists, philosophers, political theorists, economists, and imperial administrators, have accepted the basic distinction between the East and West as the starting point for elaborate theories, epics, novels, social, descriptions, and political accounts concerning the Orient, its people, customs, "mind," destiny, and so on (pp. 2-3). According to Said, orientalist distinction of the 
world as the West and the East is totally superficial and produced by the West and it exists only in the imaginative geography; it is also an unjust hierarchical dualism. Lastly, Orientalism suggests "[t]he corporate institution for dealing with the Orient - dealing with it by making statements about it, authorizing views of it, describing it, by teaching it, settling it, ruling over it: in short, Orientalism as a Western style for dominating, restructuring, and having authority over the Orient" (Said, 1979, p. 3). So Said recognizes Orientalism as a long-established western deed relied on the standardization of the western values i.e. the delineation of the western values as objective ones; and in effect, this view constitutes the point of departure for the whole critique of Orientalism. While the first definition of Orientalism is referring to the cultural and political relations between European and non-European world, the second and third definitions are not so innocent. They are of significance in the sense that they suggest the prejudiced stereotypical views of the Orient and oriental constructed by western scholars, authors, anthropologists, sociologists and philologists. These attitudes, for Said, are always normative, prejudiced, deceitful, Eurocentric, negative and even antagonistic and inherently criminal. The critiques directed to Orientalism were due to its qualities revealed in these two designations of the term. This study will also take these meanings of the term as essential in the analysis of Christie's novel. In Said's "Orientalism Reconsidered" we are given a definition of Orientalism similar to those given in Orientalism. Emphasizing the superficiality and constructed nature of the division Said (1985) wrote:

the ideological, suppositions, images and fantasies about a currently important and politically urgent region of the world called the Orient. The relatively common denominator between these three aspects of Orientalism is the line separating Occident from Orient and this, I have argued, is less a fact of nature than it is a fact of human production, which I have called imaginative geography. This is, however, neither to say that the division between Orient and Occident is unchanging nor is it to say that it is simply fictional (p. 90).

Said, in Orientalism, without making a distinction between the literary and non-literary texts, argues that texts dealing with the Orient and oriental share similar qualities and have affinities in two respects: intent and effect. Drawing on Foucault's works and his theory of power and knowledge in particular, Said uses the term discourse and claims that the Orientalist discourses are those about the East and easterner written from the vantage point of the westerner. So it is discourse through which the Orient and oriental are repeatedly imagined, created, represented, shaped and imposed. Said (1979) states:

My contention is that without examining Orientalism as discourse one cannot possibly understand the enormously systematic discipline by which European culture was able to manage-even to produce-the Orient 
politically, sociologically, militarily, ideologically, scientifically, and imaginatively during the post-Enlightenment period (p. 3).

Said believes that a full understanding and analysis of the politics of Western ethnocentrism must begin with the question of representation as formulated by Foucault. In his Archeology of Knowledge (2002), Foucault scrutinizing the history of knowledge and making a strong relation between language and power asserts that knowledge is gained through a discursive process in which discourses are produced by power. As Bill Ashcroft and Hussein Kadhim (2001) note, "[t]he discursive construction of 'Africa' and 'the African' is a profound demonstration of the link between knowledge and power, and reaches even more deeply into the imagination of the West than does the Orient" (p. xiv). According to Foucault's view, what we know actually is provided by means of the discursive formation of knowledge; that is, a discourse is generated by other discourses residing in a network of discourses. It is because of this reason that any author cannot produce a text authoritatively and subjectively and that his text has and will always have the traces of all other texts. Moreover, it is also impossible for us to know the past/history objectively because the knowledge of the past comes through the present by means of discourses, which have actually been governed by various discourses remote from our own time. As we view the past through discourses, we can never possess a thorough objective knowledge of history. Foucault (2002) asserts that a discourse "is constituted by a group of sequences of signs" and defines discourse as "a group of statements that belong to a single system of formation". Thus, he continues, "[we] shall be able to speak of clinical discourse, economic discourse, the discourse of natural history, psychiatric discourse" (Foucault, 2002, pp. 70-71). Robert Young (1990) makes a clear connection between Foucault's "discursive practice" and Said's taking Orientalism as a discursive formation:

Foucault, [...] contended that knowledge is constructed according to a discursive field which creates a representation of the object of knowledge, its constitution and its limits; any writer has to conform to this in order to communicate, to be understood, to remain 'in the true', and thus to be accepted. Said shows how this also works for the European constructions of knowledge about other cultures. Orientalism argues that a complex set of representations was fabricated which for the West effectively became 'the Orient' and determined its understanding of it, as well as providing the basis for its subsequent self-appointed imperialist rule. Disclosing a closely interrelated web of writings that stretch from literary, historical, scholarly accounts to political, military, and imperial administrative ones, Said suggests that the former produced the Orient for the eventual appropriation by the latter.

As this might indicate, what Orientalism demonstrates above all is the deep complicity of academic forms of knowledge with institutions of power (p. 166). 
The Orient-Occident dichotomy, in Said's view, is central to Orientalism and artificial and the Orient a construct of the discourse of Orientalism. Said (1985) puts the case as such: "In so far as it was a science of incorporation and inclusion by virtue of which the Orient was constituted and then introduced into Europe, Orientalism was a scientific movement whose analogue in the world of empirical politics was the Orient's colonial accumulation and acquisition by Europe. The Orient was therefore not Europe's interlocutor, but its silent Other" (p. 93). Orientalism focuses mainly on the idea that over the past two centuries the West represented the Orient and oriental, not only in its literature but also in other kinds of texts such as historical and colonial documents, travelogues, official reports, political tracts, journalistic texts and the like. Therefore, European representations of the Orient constantly constructed the East and eastern culture and values as "irrational feminine Other opposed to the rational masculine West" (Harris, 2010, p. 194). In Said's view (2009), the Orient was also feminized as passive, exotic, sexually alluring, submissive, (pp. 182, 206, 220), "silent and supine" (p. 138) while the West was masculinized as dominant, rational and self-controlled, penetrating and possessing the East as traveller. (Here an analogy may be drawn between the ways of marginalization and subjugation of the East by western thought and woman by the patriarchy: Irrationality/stupidity has been attached to the oriental people; likewise, irrationality has always been attached to woman. Rationality has always been directly related with the European and masculinity.) Said also argues in Orientalism that Orientalism both served and was engendered by the process of imperialism by means of creating a textual and virtual reality of the Orient and oriental. Therefore, Orientalism became a device in imperialism to legitimize western hegemony on the colonized countries and their people with its consistent implication that the West was more civilized and powerful than the East so the West has a civilizing mission, and imperialism was a process of civilization of the non-western countries.

Though Said (1979) takes the end phase of the $18^{\text {th }}$ century as a wake of Orientalism and "a very roughly defined starting point" (p. 3) for Orientalism due to his assertions that "Western hegemony over the Orient during the period from the end of the eighteenth century" (p. 7) and that the Orient "was not academically conquered for Orientalism until, during the later eighteenth century" (p. 51), Himmet Umunç (2013), in one of his essays, points out that the connections between the East and the West actually dates back to the ages earlier than the $18^{\text {th }}$ century: "Looked through a historical perspective, the East, for the Westerners, became the embodiment of fantastic perceptions and cultural oppositions. Yet, Turkey has been recognized as a concrete geographical place of this image after the settlement of Turks in Anatolia and during the period of the Ottoman Empire in particular" (p. 298). This may be attributable to Anatolia's geographical location. Anatolia may be considered to be a bridge between the East and the West. Western people who wished to go further in the Orient had to encounter first the Turkish world. Thus with its exoticism and mystery, the Turkish world was the first to attract the attention of 
the Western world, and Turkish people and culture represent the first Eastern people and culture which the European people encountered long before the $18^{\text {th }}$ century. Along with this simple explanation, there are, of course, many complex historical analyses of the encounter between the West and Turks. ${ }^{2}$

Meanwhile, Said's taking the end phase of the eighteenth century as the time which saw the intensification of Orientalism by means of its various shapes that pervaded in those times should not be understood as a lack in Said's Orientalism. Said was well aware of the fact that the relation between the East and West dates back even to the time of Homer. He claims that a westerner is aware of the fact that "one [a westerner] belongs to a power with definite interests in the Orient, and more important, that one belongs to a part of the earth with a definite history of involvement in the Orient almost since the time of Homer" (p. 11). He also writes that

as early as Aeschylus's play The Persians the Orient is transformed from a very far distant and often threatening Otherness into figures that are relatively familiar (in Aeschylus's case, grieving Asiatic women). The dramatic immediacy of representation in The Persians obscures the fact that the audience is watching a highly artificial enactment of what a nonOriental has made into a symbol for the whole Orient (Said, 1979, p. 21).

Orientalism is also full of references to, for instance, Euripides (p. 57), "Homer, Alexander, Caesar, Plato, Solon, and Pythagoras" (p. 85) and many other classical, medieval and Renaissance writers with their orientalist attitudes along with "Chaucer, Mandeville, Shakespeare" by whom the term 'Oriental" was canonized (p. 31) (here Said also alludes to Dryden, Pope and Byron but they have been excluded from the quote because they do not belong to the period before the $18^{\text {th }}$ century). But why does Said allude to the oriental deeds of the authors who lived before the $18^{\text {th }}$ century on one hand and on the other, exclude taking the eighteenth century as the wake of Orientalism? Due to the methodological problems, Said had to find out a starting point for his study and

\footnotetext{
2 For further information, see Thierry Hentsch's Hayali Doğu: Batı'nın Akdeniz'li Doğu'ya Politik Bakışı. (Aysel Bora, Trans.). (İstanbul: Metis Yayıncllı Ltd., 1996). Throughout this comprehensive book, which was originally written in French as L'Orient Imaginaire and translated in English as Imagining the Middle East, Hentsch presents the outcomes of his subtle inquiries about the western perception of the East and the eastern as well as the historical, political, economic, cultural and social reasons of the false and negative image of the East in western perception and discourses by means of a historical outlook and meticulous analyses of a range of orientalist works. He shares with Said the idea that the East is a concept which has been imagined and fictionalized by the West. Hentsch gives information about the encounter between the West and the Turks and also reveals, in many parts of his book, the orientalist attitudes of the West towards Turks seen throughout history.
} 
delimit his scope. The act of beginning, for Said (1979) "necessarily involves an act of delimitation by which something is cut out of a great mass of material, separated from the mass, and made to stand for" (p. 16). The following explanation also gives us the answer:

It has seemed to me foolish to attempt an encyclopedic narrative history of Orientalism, first of all because if my guiding principle was to be "the European idea of the Orient" there would be virtually no limit to the material I would have had to deal with; second, because the narrative model itself did not suit my descriptive and political interests; third, [...] there already exist encyclopedic works on certain aspects of the European-Oriental encounter (Said, 1979, p. 16).

While defining his book Said (1979) draws its framework, being conscious of the richness of Orientalist discourse in the western world: "Yet even though it includes an ample selection of writers, this book is still far from a complete history or general account of OrientaJism" (p. 24). It is obvious that Said deliberately excluded, from his work, the Orientalism taking place before the $18^{\text {th }}$ century and comprising the encounter between the West and East, and the first encounter between westerners and Turks. Another reason may be because Said wanted to focus on less the historical context than the analyses of the narratives including Orientalist approach written after 1770. Said (1979) writes: "The difference between representations of the Orient before the last third of the eighteenth century and those after it (that is, those belonging to what I call modern Orientalism) is that the range of representation expanded enormously in the later period" (p. 22).

Said defends the idea that the orientalists especially the $19^{\text {th }}$ century orientalists played a decisive part in the formation of the negative images of the Orient. At the core of Said's Orientalism lies the idea that Orientalism was built around a distinction between the East and West $^{3}$ and it manufactured the Orient, which paved the way for a constant and static definition of the Orient and oriental and the recognition of them as timeless and essential entities; thus Orientalism has acted as a basis for European ethnocentrism and European justification of colonialism and imperialism. "Dichotomizing the world into an East/West, We/They contrast, Orientalism then produced an essentialized, static Other, allowing Orientalist scholars to speak with paternalistic ease of 'The

\footnotetext{
${ }^{3}$ Hentsch marks the Hellenistic times as the wake of the division between the West (represented by the Greeks) and the East (represented by Persians) because with the rise of the Greek and Roman culture the West had found its own roots in history. Thus, the West would put its own base on a solid historical foundation at a time when there was not Europe, and the division between The East and West was based on the differences between them. However, the criterion taken to make such a division was the perspective of the westerner. Hayali Doğu. (İstanbul: Metis Yayınclık, 1996), pp. 22-27.
} 
Arab', 'The Oriental Mind" (Pennycook, 1998, p. 163). What Said attacks is the discursive formation of Orientalism based on a manufactured difference between the East and West - a difference misrecognized as essential and timeless. As it has been stated in the part of the study presenting Said's theories on Orientalism, Europe's creating oppositions in which western values are presented as objective and normative is the starting point for the critique of Orientalism in general. Said also directs his assaults on the Orientalists' confirmation of the supremacy of European modes of thought and their identity resulting in the justification of the colonialist intervention in each Eastern part of the world.

In Orientalism, Said explored how the Orient and orientals were constructed by means of both factual descriptions as in the case of journalistic texts and travelogues and imaginative representations such as novels. Death on the Nile $e^{4}$ may be explored to find out the traces of Orientalist attitude toward non-European world and people. From now on the study will deal with the detection of the novel's projection of the Orient and the oriental.

\section{The Representation of the Orient and Oriental in Death on the Nile}

The eastern world and people have always been an area of investigation for western people especially during the period of high imperialism covering the late years of the $19^{\text {th }}$ century. Likewise they have always attracted the attention of western authors and thus become subject matters in their writings. Agatha Christie (1890-1976), the detective fiction novelist employed the eastern world as setting and eastern people as characters, if not the major characters, in some of her novels. Though Christie's novels and short stories offer little character analysis, detailed description and no life philosophy, hardly any reader of the English novel is unfamiliar with Christie's novels due to their intriguing plots and inviting the reader's inference to solve the mystery. As Christie (2010) herself notes, most of her books can be described as "light-hearted" thrillers and "frivolous books" (pp. 251, 267, 306). However, she is the Queen of classic detective fiction and a prolific writer with her 70 detective and mystery novels and thrillers as well as 149 short stories and more than a dozen of plays (Kelleghan, 2001, p. 155). In Death on the Nile most of the action takes place aboard the SS Karnak, a cruise ship steaming between the First and Second Cataracts of the Nile and stopping at the sites of archeological significance.

4 Christie, Agatha.. Death on the Nile. Retrieved October 15, 2015 from https://kohledeyes.files.wordpress.com/2016/01/death-on-the-nile-by-agatha-christie.pdf (All the subsequent references to the novel will be to this e-book and only page numbers will be given in parentheses following the quotations in the main text.) 
The action in Death on the Nile may be summarized as in the following: Linnet Ridgeway, a rich American heiress living in London and Jacqueline de Bellefort are close friends. Linnet with the aim of giving a job to Jacqueline's fiancé, Simon Doyle, who is handsome but penurious, is introduced to him. He needs a job to earn his living and be able to marry Jacqueline, whose financial condition is not good, either. Linnet not only steals Jackie's fiancé but marries him. The couple decide to spend their honeymoon in Egypt. Jackie, to take revenge from Linnet and Simon, starts showing up at all the places including the cruise ship where the newlyweds are present and thus makes them harassed. Hercule Poirot and all other characters that are introduced to the reader in the exposition part of the novel appear on the cruise ship on the Nile, too. Poirot is vacationing in Egypt and the others are having an excursion. One night during the trip, Jackie shoots Simon in the leg with her own pistol upon the discussion between them - a so-called discussion as the reader will learn later on. A murder also occurs on the same night: Linnet Doyle is shot in her hand there is a letter ' $\mathrm{J}$ ' scripted on the mirror in her cabin seeming to have been written with Linnet's blood by herself. Accompanied by one of his older friends, Colonel Race, Poirot takes on the case. Poirot is sure that the murder has not been committed by Jackie as she is given, by the doctor, the drug that has made her sleep and as she has been taken care of by Miss Robson's nurse, Miss Bowers in her own cabin all night. While Poirot and Race are investigating who the murderer may be, two other murders are committed. Both Linnet's maid Louis Bourgeot and one of the passengers, Mrs. Otterbourne are killed. The detective, just in the nick of time, reveals who the murderer and his accomplice are. Simon and Jackie's plot on Linnet comes out. The excursion ends and justice triumphs over the evil, in this case greediness, once again.

Expertly plotted and set in an exotic background in the former British colony of Egypt $^{5}$, Death on the Nile offers a postcolonial analysis from the perspective of Edward Said's critique of Orientalism. In this study, Western

\footnotetext{
${ }^{5}$ Egypt was a British colony between the years 1882-1956. After the Egyptian Revolution of 1952, with the withdrawal of British forces from Egyptian troops, and in accordance with the Anglo-Egyptian Agreement in 1954, the occupation of Egypt by British forces ended gradually. Thus Egypt declared independence in 1956. For further information about the colonization of Egypt by Britain see Eve M. Troutt Powell. A Different Shade of Colonialism: Egypt, Great Britain, and the Mastery of the Sudan. (Berkeley: University of California Press, 2003). See also David M. Dixon "Some Egyptological Sidelights on the Egyptian War of 1882" in Views of Ancient Egypt since Napoleon Bonaparte: Imperialism, Colonialism and Modern Appropriations. Ed. David Jeffreys. (London: Institute of Archeology, 2003). pp. 87-94. For the information of the beginning of British occupation of Egypt, and of British intervention in affairs of state of Egypt, see in the same book Fekri A. Hassan "Imperialist Appropriations of Egyptian Obelisk" for the Suez crisis that ended the British occupation in Egypt though "Britain and France, in alliance with Israel, invaded Egypt to re-establish control and take possession of the Suez Canal". p. 64.
} 
image of the Orient and oriental in Death on the Nile has been studied under two headings:

\section{Western Image of the Orient in Death on the Nile}

Orientalist attitudes are directly related with the colonial desire of the European people and this desire has sometimes been expressed as a duty, responsibility or mission of the civilized and has sometimes been reflected as a right owing to the assumption that the West is more civilized, advanced and modern than the East. The colonial desire is based on the diversity between the East and West. Christie's recognition of The East and West as the world's separate parts having opposing qualities shows her orientalist attitude in the novel. While she is reflecting the West as civilized, she portrays the East as uncivilized. The Orient's backwardness is stressed by Dr. Bessner, who advises to take Simon Doyle shot in his leg to the civilization where he can be cured properly. Finding the cruise ship on the Nile primitive, the doctor says: "We will get him to civilization and there we will have an X-ray and proper treatment" ( $p$. 92). A steamer cannot, of course, be expected to serve as a well-equipped hospital but the choice of word "civilization" is worth noting here in terms of its reference to the western world.

Rosalie Otterbourne, the drunken writer of pornographic novels, defines Egypt as a place having a bad effect on her: "There's something about this country that makes me feel wicked. It brings to the surface all the things that are boiling inside one. Everything's so unfair - so unjust" (p. 49). For Mrs. Otterbourne it is the Oriental world that arises in one the negative perhaps dangerous feelings. This is the stereotyped image of the East as degenerate. For this reason she makes a connection between the murder of Linnet Doyle's maid Louise Bourget and the suspect, Fleetwood:

"The crime passionnel!" she exclaimed. "The primitive instinct-to kill! So closely allied to the sex instinct. That girl, Jacqueline, half Latin, hotblooded, obeying the deepest instincts of her being, stealing forth, revolver in hand-" [...]

"Her husband, then," said Mrs. Otterboume, rallying from the blow. "The blood lust and the sex instinct-a sexual crime. There are many well-known instances."

"Mr. Doyle was shot through the leg and he was quite unable to movehe bone was fractured," explained Colonel Race.

"He spent the night with Dr. Bessner." Mrs. Otterbourne was even more disappointed [...]

"Yes. Naturally. It's so clear psychologically. Repression! The repressed virgin! Maddened by the sight of these two - a young husband and wife passionately in love with each other. Of course it was her! She's just the type-sexually unattractive, innately respectable. (pp. 106-107) 
According to Said (1979), orientalists produced the Orient as an object of fascination and exoticism, which results in the Orient's becoming an object of study in the hands of the European. The East was delineated as a fascinating exotic place in the discourses produced by westerners. This approach to the Orient is perhaps the oldest and the most clichéd one. Exoticism seems, for the non-European people, to be both an appealing quality of the East and also its differentiating quality when compared to the West. The reflection of the East as fantastic and exotic existed in the Greek and Roman historical documents written in the $1^{\text {st }}$ century B.C. and went on in the European discourses in the Middle Ages. That is why, it is a "traditional exoticism" and "perdurable exoticism" (pp. 26, 92). As Umunç (2013) also points out, this portrayal was accompanied by the negative reflection of the East, which "is described as the symbol of moral degeneration stemming from debauchery" (p. 299). Therefore, ambivalence aroused in the depiction of the Orient and oriental in western discourses. On one hand, some discourses embedded with the oriental romanticism and fantasies appeared, on the other prejudiced, solipsistic discourses othering the Orient and Oriental in an antagonistic vision were begun to be produced (Umunç, 2013, p. 313). Death on the Nile presents exoticism of the Orient from time to time through its characters despite its negative approach to the Orient. There is an exotic trip which forms the basis for the novel. It is known that Christie had many travels to the Middle East with her archeologist husband Max Mallowan for the archeological expeditions. Christie's biographer Charles Osborne (1937) notes that "Christie's interest in the Middle East as a locale for her novels was not confined to those parts where she and Max Mallowan had been engaged in archaeological endeavours" (p. 449). They had also travelled in Egypt, both ancient and modern, for pleasure. Death on the Nile is a novel written after such expeditions. Nonetheless, her reflecting Egypt as exotic, romantic and fascinating place might be thought to have emerged from the clichéd Orient. For example, Egypt becomes a fascinating and romantic place for the newlywed couple to spend their honeymoon and Hercule Poirot prefers to enjoy a vacation aboard the SS Karnak, steaming between the First and Second Cataracts of the Nile, with stops at sites of archaeological significance. Likewise for the American old lady Miss Van Schuyler, who is very rich and visited some places in Europe such as Paris, Egypt is among the interesting places which one must see. For Mrs. Allerton and her son Tim, Egypt is so expensive and far away from Europe that one cannot go there easily, it is still attractive for Mrs. Allerton, who wishes to see the "lazy golden sands" and "go up the Nile" (p.16).

A similar mindset can be noticed in Christie's reflection of the oriental history and culture. In the following scene, those looking at the great statues on the face of the mountain seem to be affected by their grandness and beauty, which can be considered a positive attitude. Yet, it is a stereotypical and Western constructed attitude because the characters are observed to be impressed by them on one hand, on the other they prefer to attach their 
personal feelings with the figures rather than trying to understand their real meanings in Egyptian history:

On the Monday morning various expressions of delight and appreciation were heard on the deck of the Karnak. The steamer was moored to the bank and a few hundred yards away, the morning sun just striking it, was a great temple carved out of the face of the rock. Four colossal figures, hewn out of the cliff, look out eternally over the Nile and face the rising sun.

Cornelia Robson said incoherently: "Oh, Monsieur Poirot, isn't it wonderful? I mean they're so big and so peaceful-and looking at them makes one feel that one's so small and - and rather like an insect - and that nothing matters very much really, does it?"

Mr. Fanthorp, who was standing nearby, murmured, "Very impressive." "Grand, isn't it?" said Simon Doyle, strolling up. He went on confidentially to Poirot: "You know, I'm not much of a fellow for temples and sightseeing and all that, but a place like this sort of gets you, if you know what I mean. Those old Pharaohs must have been wonderful fellows." (p. 62)

In the following excerpt, a mode of exoticization of the Orient akin to the one in the previous extract has been employed by Christie:

Silence fell on the three of them [Hercule Poriot,Rosalie Otterbourne and her daughter]. They looked down to the shining black rocks in the Nile. There was something fantastic about them in the moonlight. They were like vast prehistoric monsters lying half out of the water. A little breeze came up suddenly and as suddenly died away. There was a feeling in the air of hush-of expectancy (p. 28).

Egypt, by the author of obscene novels, Mrs. Otterbourne, is associated with sexuality and thus it is the source of inspiration for her novels. She explains Pairot that the purpose of her coming to Egypt is to provide "local colour" and subject matters for her new novel:

"I don't mind telling you, Monsieur Poirot, I am partly here for local colour. Snow on the Desert's Face - that is the title of my new book. Powerful - suggestive. Snow-on the desert-melted in the first flaming breath of passion." [...] "One must be strong," went on Mrs. Otterbourne, wagging the turban emphatically. "Strong meat - that is what my books are - all important. Libraries banned - no matter! I speak the truth. Sexah! Monsieur Poirot - why is everyone so afraid of sex? The pivot of the universe! (p. 26)

This association may be thought to have stemmed from the erotic imagery of the East due to Harem and belly dance, which have been well-worn images of the Orient. The novelist's claim to be taking the Nile cruise for local colour for 
her future novel can also be regarded as the westerner's exploitation of the exotic East for his own benefits.

Egypt is defined as an outpost of Empire while the narrator introduces Colonel Race, a friend of Hercules Poirot: "He was usually to be found in one of the outposts of Empire where trouble was brewing" (p. 69). The idea given here is that Egypt as a colony of the mother country becomes a trouble for England as the other colonies are. Yet it is a place which should be under the European control and domination, which is embodied, in this context, by Colonel Race. This expression of Christie's narrator is an exact confirmation of the orientalists' supposition that eastern people should be under the control of western domination because they are primitive, barbaric and in a state of chaos, and etc., and therefore they need an order restorer.

Death on the Nile contains references to not only oriental place, environment but also the oriental objects. For instance, Poirot considering that Simon and Linnet are a wealthy couple asks Simon why they did not engage their own "private dahabiyeh", (p. 62) ("also known as "dahabeeah/dahabeeyah/dahabiah") - "a houseboat used on the Nile" (http://www.collinsdictionary.com/dictionary/english/dahabeah\#dahabeah 1). In another instance Christie refers to "brightly painted scarlet basket chairs outside the Cataract Hotel at Assuan" (p. 19). Mrs. Allerton and her son Tim are sitting on these chairs. The chairs are reflected as they are in an inconvenient colour and situation. The steamer SS Karnak is also a cruise ship that was peculiar to the Orient and could be seen very often on the Nile in those times.

As a conclusion, if we bear in mind that in 1937, "the Nile was as exotic to the majority of Christie readers as Mars is to her current audience: very few travelled abroad for holidays, if, in fact, they took holidays at all" (Curran, 2009, p. 136), we can argue that Death on the Nile, with its reflection of Egypt in terms of its exoticism, fantasy and eccentricity along with its diversity from the West, must have formed this image of the Orient in the western mind and reinforced the diversity between the Orient and Occident.

\section{Western Image of the Oriental People and Values in Death on the Nile}

What takes one's attention in Death on the Nile with respect to the image of the oriental people is their stereotypical representation. People of the Orient were employed as background characters in the novel. By means of this type of representation of the oriental people, the author puts the western people in the centre and the eastern on the periphery. People of the Orient are always portrayed in an unfavourable way as well. They are depicted either as servants, porters (p. 49), boatmen (pp. 44,48), donkey boys (pp. 21,55) or as waiters (pp. 27, 122), steward (pp. 52, 82, 86, 95, 99, 115, 123, 124, 125, 127, 132, $148,157,158,160$ ) (on many pages more than once), stewardess (pp. 132,133, $171,174,175,176)$ (on some pages more than once), dragomans (pp. 56, 63) 
and beggars (pp. 64-65). The reference to the orchestra in Chez Ma Tante, where Poirot frequently eats his dinner, is interesting in the sense that it is an indication of stereotypical depiction of the non-white people. "The Negro orchestra broke into an ecstasy of strange discordant noises. London danced" (p. 25). This kind of employment of the native characters, i.e. the employment of them as stock characters in the novel gives one the idea that natives constitute only the labor force in the world of westerners.

In the formation of the negative images of the oriental people, the diversity between the oriental people and westerners is of great significance because on the whole this diversity accomplishes a constitutive role in the formation of collective identities. Differences between easterners and westerners are accentuated by Christie in her novel, and therefore her discourse is orientalist in the sense that she based her mode of defining her characters on the deep-seated diversity between easterners and westerners. Thus the novel naturalizes this diversity and also strengthens the negative image of the oriental people.

As in many other oriental discourses, in Christie's novel it is recognized that the 'Other' (the oriental people) is perceived by the 'Self' (the European) as radically different from the 'Self' and inherently having negative inferior qualities. The 'Other' is always dissimilar and opposite of the 'Self'. Whenever Christie attributes a negative image to an oriental character, the opposite of this image is found in a European character. From many instances in the novel, Poirot's being put in charge of the case may be given as an example. While Poirot is drawn as a wise European image to investigate the case, the captain of the steamer, even without asking any question to anybody, draws back. (The scene will be referred in detail later on in the relevant part.) The novel always gives the reader the sense that non-western characters are always inferior to western characters. The other point concerning Christie's use of the 'Self' and 'Other' dichotomy is that the 'Other' becomes an object of defining the 'Self' in Christie's hands. Stressing the Other's otherness, Christie actually defines the 'Self'. Thus Death on the Nile can be claimed to participate in the naturalization process of the dichotomy between the self and the Other and to reinforce the inferiority and otherness of the easterner.

One of the most important features of Orientalism was Europeans' defining themselves by defining the orientals. As Said (1979) puts it in the part, "The Scope of Orientalism" in Orientalism, generalizing takes a great part in such identifications. When the non-western people are defined as, to name, irrational and backward, the Europeans automatically became rational and civilized. Said (1979) emphasizes that "the Orient has helped to define Europe (or the West) as its contrasting image, idea, personality, experience" (p. 2). It is apparent that the identifications of both westerners and easterners rely on the binary oppositions, the favourable elements of which are always attached to the West to make it superior to the East, and the unfavourable parts of which are 
always attributed to the East only to make it inferior. Said regards this opposition or the dialectic between the self and other as crucial to European self-conception. Loomba (1998) also points out that

If colonized people are irrational, Europeans are rational; if the former is barbaric, sensual and lazy, Europe is civilization itself, with its sexual appetites under control and its dominant ethic that of hard work; if the Orient as static, Europe can be seen as developing and marching ahead; the Orient has to be feminine so that Europe can be masculine (p. 47).

The westerner's defining his own self through othering the easterner poses "epistemological and ontological" problems in Said's term (1979, p. 2). While the West via its own western view is identifying the oriental as the negative 'Other' of the West, it defines itself by means of using the opposites between them, and therefore an epistemological problem arises: the knowledge about the oriental is achieved by means of the western criteria and perspective, which become the means of identification of and understanding the oriental. An ontological problem also arises in the West's defining the East and eastern because the West regards the East as an existence that always lives in the past so it is backward rather than modern and civilized and also dependent on the West. Therefore, the eastern identity which is peculiar to it has always been recognized through the eyes of the westerner and eventually it has come to disappear.

In the scene in which Simon is shot by Jackie, an orientalist attitude of the writer's to the Eastern people is observed. Simon, upon hearing someone approaching, in order to cope with the situation, tells Fanthorp "to say it's all right - an accident - something. There mustn't be a scandal over this." In the following part, Christie's choice of words that are used to refer to both the European (represented by Fanthorp here) and non-European (represented by the steward in this context) is evidence enough to reveal her orientalist attitude: "Fanthorp nodded in quick comprehension. He wheeled round to the door where a startled Nubian face showed. He said: "All right all right! Just fun!" The black face looked doubtful, puzzled, then reassured. The teeth showed in a wide grin. The boy nodded and went off' (p. 78). (Emphasis is mine).

Likewise, the depiction of donkey boys, bead sellers and shopkeepers in the novel is noteworthy in the sense that it is the proof of Christie's attributing negative and unfavorable references to the Oriental people. The narrator describes vendors as in the following: "They came out from the shade of the gardens onto a dusty stretch of road bordered by the river. Five watchful bead sellers, two vendors of postcards, three sellers of plaster scarabs, a couple of donkey boys and some detached but hopeful infantile riff-raff closed in upon them" (p. 21). They are reflected with their lack of English, which is a sign of Westerners' recognition of themselves as superior to the Eastern people. 


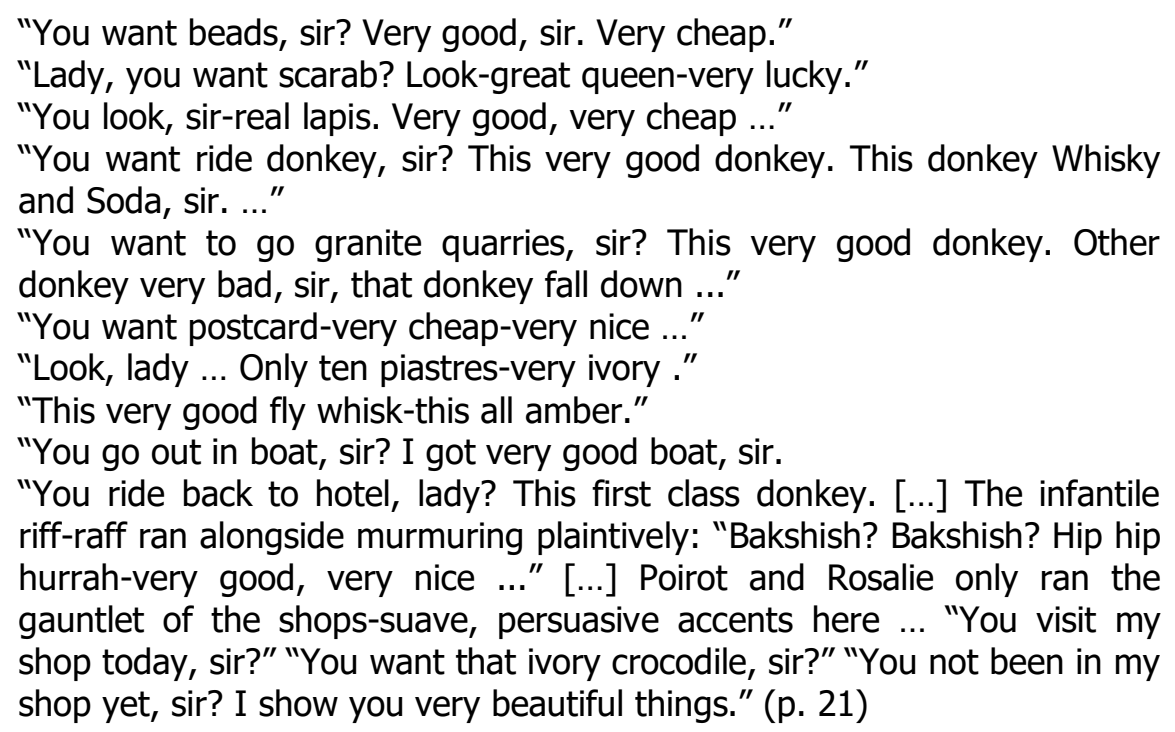

In another scene, Mrs. Allerton is seen being reflected as a westerner trying to get rid of the native children and finding their eyes and noses disgusting. This is clearly a racist attitude toward them:

\begin{abstract}
"Good-morning," she said. "I suppose it would be quite impossible to get rid of some of these awful children." A group of small black figures surrounded her, all grinning and posturing and holding out imploring hands as they lisped "Bakshish" at intervals, hopefully. "I thought they'd get tired of me," said Mrs. Allerton sadly. "They've been watching me for over two hours now-and they close in on me little by little; and then I yell 'Imshi' and brandish my sunshade at them and they scatter for a minute or two. And then they come back and stare and stare, and their eyes are simply disgusting, and so are their noses, and I don't believe I really like children-not unless they're more or less washed and have the rudiments of manners." (p. 55)
\end{abstract}

As the foregoing excerpt portrays, the native is made the racial Other by westerners even if they are not adults but children. The character here can be observed to be discounting and objectifying the natives. This is also a textual construction of the Oriental Other by the author.

In the following part of the novel there is another degradation of the native people. Their children are reflected as beggars, who even created a game and a song from their act of begging:

They [Linnet and Simon] came out of the temple into the sunshine with the sand yellow and warm about their feet. Linnet began to laugh. At their feet in a row, presenting a momentarily gruesome appearance as 
though sawn from their bodies, were the heads of half a dozen Nubian boys. The eyes rolled, the heads moved rhythmically from side to side, the lips chanted a new invocation: "Hip, hip hurray! Hip, hip, hurray! Very good, very nice. Thank you very much."

"How absurd! How do they do it? Are they really buried very deep?"

Simon

produced some small change.

"Very good, very nice, very expensive," he mimicked.

Two small boys in charge of the "show" picked up the coins neatly. (pp. 64-65)

In the description of the oriental people Christie employed animal imagery as well. This is another way of the author's marginalizing the people of the Orient in the novel. For example, the crowd of sellers around Hercule Poirot and Rosalie is defined as "human clusters of flies". Christie extends the metaphor and states that "[t]heir gaily coloured rags trailed picturesquely, and the flies lay in clusters on their eyelids. They were the most persistent. The others fell back and launched a fresh attack on the next $\operatorname{comer}^{\prime \prime}$ (p. 21).

Poirot and Rosalie's way of getting rid of the vendors also imply the idea that they both see the oriental people as simple and stupid: "Hercule Poirot made vague gestures to rid himself of this human cluster of flies. Rosalie stalked through them like a sleep walker. "It's best to pretend to be deaf and blind", she remarked" (p. 21). It is obvious that orientals are essentially portrayed in the novel as simple, stupid and uncivilized. They are also depicted as people in need of the western people's taking pity on them as well as their help and money. Thus the scene reinforces the opposition between the peripheral and central positions of the eastern and western respectively.

The stupidity of the oriental people is accompanied with their disunity in work in another part of the novel. According to the Western people the natives are such simple creatures that they act in a disorganized way, which implies the idea of their being lax. Because they work in an unplanned way, the train is late and there is a collision of the baggage loaded and unloaded: "The train from Cairo and Luxor was about twenty minutes late. However, it arrived at last, and the usual scenes of wild activity occurred. Native porters taking suitcases out of the train collided with other porters putting them in" (p. 49). Besides, the working boys become an object of ridicule for Jacqueline de Bellefort. "She laughed and mimicked the parrot cry of the donkeyboys" (p. 55).

As mentioned previously, in Orientalism Said exposes the ways in which the European constructed the Orient. The very first way of forming the Orient is westerners' terming the East, in opposition to the West, as an 'Other'. The 'Other' has constantly and ostensibly been defined as an observer who has the qualities opposing to those of Westerners. The 'Other' is dishonest, lazy, dirty, uncivilized, degenerate, lecherous, perverse and silent in contrast with the 
European who is honest, industrious, civilized, moral, sexually restrained, intelligent, sophisticated and so on. Creating an 'Other', the European actually fortified his own identity, which is, for Said, the essential function of Orientalism. Thus, the 'Other' is always objectified, and it operates as the West's "contrasting, image, idea, personality [and] experience (Said, 1979, pp. 1-2). In Death on the Nile, similar adjectives such as dishonest, furious, revengeful are always attached to the oriental people. This approach to the oriental people may be considered to be an extension of the clichés pervaded by the previous discourses which contributed to the collective consciousness of the westerners to consider non-European as different from westerners and label them with the negative qualities that are exactly opposed to those attached to themselves. This is a production of their western mind and perspective via their western criteria. To elaborate this argument, an example to such discourses which endorse the views that the oriental is the 'Other' of the westerner and that the oriental can only be defined by the negative qualities - the qualities opposing to ones used in the identification of westerners - can be given. It is a travelogue written by Jean Thévenot, in which he describes Egyptians. Thévenot wrote that Egyptians generally have dark complexion, they are very bad, very vile, treacherous, despicable, cowardly, lazy, two-faced and grossly pederast. They are also bandits and so stingy a people as to kill men for Medina. As a result, they can commit every evil act (as cited in Hentsch, 1996, p. 119). This is just an example which, in Said's own words, 'orientalizes' the oriental people.

Christie attributes some negative qualities to not only the sellers but also the guide giving the western tourists some information about the relics in Egypt. The disinterestedness of the western tourists toward the guide serves as a sign of the construction of the image of the oriental people through literary discourses. The narrator in Death on the Nile says:

She [Cornelia Robson] prattled on until the dragoman in charge called a halt and began to intone: "This temple was dedicated to Egyptian God Amun and the Sun God RE- Harakhte-whose symbol was hawk's head ..."

It droned on. Dr. Bessner, Baedeker in hand, mumbled to himself in German. He preferred the written word (p. 56).

The guide's manner of speaking is dull, not as clear and refined as that of a Westerner. Perhaps because of this reason Cornelia wishes Dr. Bessner to be there when she is inside the temple of Abu Simbel. Chatting with Mr. Ferguson, Cornelia says: "That's a cute kind of castle there that I never noticed before. I wish Dr. Bessner was here, he'd tell me what it was" (p. 71). Dr. Bessner's having no personal involvement with the words of the dragoman in the foregoing part of the novel recurs through Signor Richetti's disinterestedness toward and disdain of the dragoman's remarks:

They [the tourists and the guide] came to a halt. The guide proceeded to instruct them on the subject of the temple built by the great Rameses. 
The four colossi of Rameses himself, one pair on each side of the entrance, hewn out of the living rock, looked down on the little straggling party of tourists. Signor Richetti [...] was busy examining the reliefs of Negro and Syrian captives on the bases of the colossi on either side of the entrance. When the party entered the temple, a sense of dimness and peace came over them. The still vividly coloured reliefs on some of the inner walls were pointed out, but the party tended to break up into groups. Dr. Bessner read sonorously in German from a Baedeker, pausing every now and then to translate for the benefit of Cornelia, who walked in a docile manner beside him (pp. 63-64).

The scene is an exact sign of orientalism, suggesting that the oriental guide is a constant nuisance in the eyes of the westerners, and that westerners see themselves as knowing and expressing the Orient better than the Orient itself. If the Egyptian guide's act of instruction is taken as a symbol of the oriental people's expressing themselves, it can be argued that Christie making her characters not listen to the guide rather prefer their own discourses about the Orient interrupts the process of representation of the Orient by the oriental people. Christie, in a sense, does not permit the eastern people to express themselves by means of silencing them and presenting them as incapable of representing themselves. This point has been problematized in Said's Orientalism. The representation of the Oriental people by themselves is one of the key arguments that Said presents in his book. Even the first epigraph of the book has been taken from Karl Marx and it reads: "They cannot represent themselves; they must be represented". It is obvious that Said used it sarcastically to criticize the tendency of the orientalists' making the oriental people silent.

In Christie's novel, the negative qualities are attached to the oriental people as well as to the westerners living and working in the Orient, and this can be seen very clearly in the case of Fleetwood. This point could have been discussed in the previous part dealing with the effects of the oriental space on people but it has been preferred to be specified in this part because it is also related with the negative aspects associated with the oriental people. Fleetwood's story constitutes one of the subplots in the novel. He is delineated as an untrustworthy, dishonest man because he works and lives in Egypt. Actually his nationality is not given but the reader may infer that he is European from his English name and the information that he has been in Egypt to earn his living. Yet because of the negative effects of the Orient, he is told to have bad qualities similar to those of the oriental people. His story unfolds throughout the novel as such: One of Linnet's maids, Marie intends to marry a man who has a job in Egypt but via Linnet's inquiry about him, which was held so that Marie could have further information about the man she would marry, the man turns out to be already married with three children (p. 3). Eventually the marriage does not come to fruition. We are told that Marie broke their relation off when she discovered that he was a married man (p. 99). It is Louise Bourget who 
informs Poirot and Race about the whole story of Fleetwood, who is also one of the mechanics on the boat:

"[Linnet] made inquiries and she discovered that this Fleetwood already he had a wife - a wife of colour you understand, a wife of this country. She had gone back to her own people, but he was still married to her, you understand. And so Madame she told all this to Marie, and Marie she was very unhappy and she would not see Fleetwood any more. And this Fleetwood, he was infuriated and when he found out that this Madame Doyle had formerly been Mademoiselle Linnet Ridgeway he tells me that he would like to kill her! Her interference ruined his life, he said." (p. 94)

Later on in the novel Fleetwood appears as a primary suspect in Linnet Doyle's murder and he is questioned by Poirot and Race. They think that Fleetwood has developed a feeling of revenge on Linnet because of the breaking off his relation with Marie. It is apparent that Christie drew her character, who has affinities with eastern people owing to his leading a life in Egypt, by means of a stereotyped image. He is represented in terms of vengefulness - a trait assigned to the oriental people. Fleetwood is accused of being a bigamist, too. Fleetwood explains the case in another way: "It wasn't like that. I married one of the locals out there. It didn't answer. She went back to her people. I've not seen her for half a dozen years" (p. 99). Upon learning that he is a suspect Fleetwood rebukes the detective and his friend:

Yes, I'll say it, I did have a grudge against the lady, and I felt bitter about it when I saw her on this boat, all dressed up in pearls and diamonds and lording it all over the place, with never a thought that she'd broken up a man's life for him! I felt bitter all right, but if you think I'm a dirty murderer - if you think I went and shot her with a gun, well, that's a damned lie! I never touched her. And that's God's truth." (p. 99)

What matters here is that the western characters in the novel see Fleetwood, just because he is a man living and working in Egypt and he is married to a local woman, as a man who tends to have negative qualities such as dishonesty, deceitfulness, vengefulness, bigamy that are all attributed to the eastern people; therefore, he is believed to be prone to kill Linnet Doyle.

Christie's making a westerner (Belgian detective Poirot) an authority to inquire the murders despite the presence of a captain on the ship may be considered to have been derived from her orientalist attitude. The view of the oriental as unwise, as opposite to the western sense of intelligence, is a well known stereotype and one that occurs in Death on the Nile. It is true that Death on the Nile is technically a detective and crime novel and there must be a detective there to solve the case(s). Nevertheless, both the captain's submitting Poirot to the crimes and the unquestionable ease by which Poirot is made the sole authority as soon as the first murder is committed are noteworthy. The 
captain not knowing what to do when Louis Bourget finds Linnet dead comes to Race, who then comes to Poirot. Race tells Poirot: "You're the man in charge. I'll take my orders from you. You say what's to be done" (p. 86). So it is possible to argue that Poirot's being automatically given the responsibility of investigating the murders and finding the murderer(s) without anybody's interference depends on the prejudices about the western and oriental people: People of the Occident are wise, intelligent, clever and they have a quick and analytical mind to solve problems unlike the people of the Orient. This proves Christie's unfavourable representation of easterners.

In Death on the Nile another orientalist attitude can be observed when an oriental and Islamic value, Mohammed, the prophet of Muslims is made an object of ridicule. Christie probably having no truth about Mohammed's life (because Christie did not have any interest - if not a special one - in Mohammed and religious doctrines in Islam at any time during her life as we infer from her biography and autobiography) and having just prejudices about him employed a (so-called) ridiculous expression in her novel. When Rosalie Otterbourne complains about her novelist mother's interest in sex, she makes a resemblance between her mother and Mohammed with respect to lechery. Rosalie seems to be ashamed of her mother. Referring to her full name, she tells Hercule Poirot of her mother's interest in sex: "Look at -at some people's mothers - and look at mine. There is no God but Sex, and Salome Otterbourne is its Prophet" (p. 49). Mohammed is ridiculed here in two ways: One is coming from the orientalists' deep-seated beliefs about and misrepresentation of Mohammed. Tibawi (2016), looking at the history of the orientalist attacks on Islam and Mohammed, points out that the fights against Islam date back to the time of the Byzantina Empire. He has the idea that the Byzantine polemicists "were in due course even surpassed by their medieval European successors in cultivating hatred and prejudice through the dissemination of abusive and false accounts. Thus to them Islam was "the work of the devil," the Quran "a tissue of absurdities" and Muhammad "a false prophet," "an impostor" or "antichrist." The Muslims were some sort of brutes with hardly any human qualities" (p. 6). Tibawi (2016) also presents what Mohammed, who "laid false claims to be the bearer of a divine message" (p. 17), means to Muslims:

Perhaps the most significant matter in which the rules of the game are often disregarded is the conception which most Orientalists entertain of the role of Muhammad as a messenger of God and the nature of the message, enshrined in the Quran, which he was commanded to convey. To the community of Islam, Muhammad is the last of God's messengers to mankind sent to confirm and complete earlier messages conveyed through former prophets. To the community the Quran is the Speech of God, eternal and uncreated, transmitted to Muhammad, at intervals, through the agency of the angel Jibril. Not only the message itself but also the call to preach it is of divine origin (Tibawi, 2016, pp. 15-16). 
Tibawi in another writing of his, "A Second Critique of English-Speaking Orientalists" concentrates his attention on the works produced by a number of orientalist authors attacking Islam in the present. He directs his assaults on the orientalists (whose names are not directly mentioned) denigrating Islam and Muslims' prophet Mohammed considering that they do not recognize Mohammed as prophet but rather Christ as God's prophet and even as the son of God (Tibawi, 2000, p.148). Tibawi (2000) points out that the orientalist missionaries did not consider Islam as an individual religion but rather an offspring of Judaism and Christianity, and they took Mohammed as "subject to Jewish and Christian influences" (p.149). By doing this, they tried to make Islam an ineffectual belief.

Hentsch marks the $11^{\text {th }}$ century as the beginning of the attacks on Islam. It is the time in which the Catholic Church produced the discourses about Mohammed, contradicting his being the last prophet and approving his being a false prophet (Hentsch, 1996, p. 61). In Hentsch's (1996) view, the primary point of departure of those attacking Islam was that Islamic doctrines seemed to be derived from both Judaism and Christianity, in other words, these three religions shared almost the same teachings and Mohammed was therefore considered to be a pervert, an imposter and a charlatan (p. 62). Hentsch (1996) also argues that these and similar non-objective beliefs about Mohammed was pervaded by the Christian Church's lavish slanders about him during the $13^{\text {th }}$ century (p. 74).

The second stereotypical image of Mohammed, which is reflected in Christie's expression, is that he is lecherous as well as perverted. This charge against Mohammed, as stated by Hentsch (1996), is a general tendency adopted by many orientalists including Peter Bayle. Bayle, (1826) in his Historical and Critical Dictionary, writes that in Islam a man is given a right to marry more than one wife. Mohammed himself "had already married nine wives, and then espoused a tenth, which he took from his servant, who murmured at it", which, of course, caused a scandal (p. 252). It is apparent that Mohammed was supposed to be sexually perverted because he was polygynist and he was also accused of having incest. This was attributed to his marrying his stepson's wife, Zeynep; but theoretically there is, in effect, no blood relation between them. Besides it is told that "this marriage had a social dimension" (Sarıçam et al., 2011, p. 83). Mohammed married Zeynep to discard the adopted idea that it was banned and it was a sin in Islam to marry one's his/her own stepdaughter/stepson. It is also believed that his marriage with Zeynep came as a complete revelation to Mohammed (Yıldız et al., 1989, p. 318). Apart from this, it is known that in Islam polygyny is not obligatory rather it is advisable and acceptable on conditions that a man's wife is chronically ill (in such a case it is better to marry twice than to leave or divorce the ill wife for the sake of social security of her), she is infertile (in such a case the man may wish to have children) or a man is in danger of committing adultery because of his over sexuality; and more importantly, one man can be permitted to marry more than 
once (this is limited to four in Islam) if he would be able to behave all of his wives really equally, which is actually impossible. In the relevant verses in the Koran, such a responsibility is attested to be improbable (Yıldı et al., 1989, p. 324). (It should also be noted in parentheses that in contrast with polygyny, polyandry, one woman's having multiple husbands, is not let in Islam.) Demircan (2003) claims the idea that in Arab and Muslim societies in the past during the Pre-Islamic Era in particular "there were social, political, cultural, economical [sic] [economic], psychological and geographical reasons" for practicing polygyny. Among them were the desire to have more sons, to resolve conflicts among tribes between the opponents of Islam, to improve political and social relationships between tribes and to assure women for a social security ( $p$. 9). Muslims and their prophet Mohammed are known to have been monogamous during the phase of Mecca but after the Hegira, they became polygynist due to the facts that; 1 . Women in Mecca who converted into Islam were young but poverty-stricken so they could not marry easily due to the rarity of Muslim men, and 2. Owing to the wars' breaking into during the phase of Medina, many women's husbands died so the women had to marry for financial reasons (Demircan, 2003, p.18).

As can be seen from both the orientalist considerations of and the past rhetoric on Islam and critiques on orientalists' attitude toward Islam, Mohammed has been recognized by a range of orientalists as an imposter due to their west-based ideas. Perhaps it would not be wrong to think that as a westerner Agatha Christie was aware of such polemics upon Islam projecting Mohammed as a false prophet, and therefore her attitude toward Mohammed as reflected in her novel may be an indirect result of polemical writings.

\section{Conclusion}

In summary, Agatha Christie seems to have adopted an orientalist attitude in her novel Death on the Nile when it comes to the reflection of the Orient and oriental although the novel does not seem to be putting forth its orientalist quality because in effect, this quality is disguised by its characteristics as a detective and crime novel. Though the novel was written through some impressions of the novelist's real life after the archeological travels to the Middle East, Christie seems to have written her novel by means of prejudices about the East and eastern people. So she produced, by her cultural bias, a discourse about the Orient making the oriental people the 'Other', focusing upon the dissimilarities between the East and West, between the easterner and westerner. By means of this study, it has been observed that throughout the novel, the author could not have helped using the clichés about the Orient as the 'Other' of West (because she reflects Egypt as different from Europe and as an exotic, fantastic and attractive place which the European people may enjoy during their excursion), the oriental people as the 'Other' of the European (because they are delineated by means of totally contrasting qualities - Christie reflects her European characters and values positively despite their defects; on 
the contrary, easterners are always drawn with negative qualities), the oriental concepts and values including their religion and religious values are always devalued and degraded in the novel. The paper also argues that Death on the Nile is an orientalist discourse because it both includes stereotypical delineations of the East and easterners and represents the western characters as central, the eastern characters as peripheral. The novel's presenting Egyptians as flunkies and Europeans and Americans as rich emerges from its orientalist quality. An explicit white superiority over easterners is so pervaded in the novel that the voice of eastern people is effaced. Through a close reading of the novel, it has been observed that Christie created the image of the East, eastern and easterner through her western perspective and she took western values as criteria in her way of judging, reflecting and evaluating them. Briefly, Christie seems to have relied on the stereotypical binary divisions between the East and West as well as the constructed and well-worn diversity between the eastern and western in the depiction of the Orient and oriental in her novel.

Bearing in mind firstly that the detective fiction has always been a popular genre and secondly that Agatha Christie's books, especially her novels have sold over a billion copies in English and another billion in 100 foreign languages throughout the world and that she is the most widely published and read author of all time and in any language, outsold only by the Bible and Shakespeare's work (Campbell, 2005, p. 18), it is not difficult to guess that her oriental novel, Death on the Nile, which has been attempted to be analyzed with respect to its western representations of the Orient and oriental in this study, must have contributed to form a negative and false image of the Orient in the westerners' mind and thus reinforcing this image in the western world, it has taken part in the orientalist discourses of the West.

As the reader might notice, the representation of the western characters in the novel has not been included in this study. However, the essay offers a study on Christie's projection of European characters to provide a contrastive analysis between the reflections of western and eastern characters in Death on the Nile, which has been thought to help to support the argument of this study from another direction. Due to the limited length of this study, it may be an area of investigation for another study. 
Western Image Of The Orient And Oriental In Agatha Christie's Death On The Nile: A Postcolonial Reading

\section{Bibliography}

Abdel-Malek, A. (2000). Orientalism in Crisis. In Alexander Lyon Macfie (Ed.), Orientalism: A Reader. (pp. 47-56). New York: New York UP.

Ashcroft, B. \& Kadhim, H. (2001). Introduction. In Ashcroft, B. \& Kadhim, H. (Eds.). Edward Said and the Post-Colonial. (pp. ix-xv). Huntington \& NY: Nova Science Publishers, Inc.

Ashcroft, B., et al. (2002). The Empire Writes Back: Theory and Practice in Post-Colonial literatures. USA: Routledge.

Bertens, H. (2002). Literary Theory: The Basics. NY: Taylor \& Francis.

Campbell. M. (2005). Agatha Christie. Great Britain: Cox \& Wyman, Reading.

Christie, A. (2010). Agatha Christie: An Autobiography. Great Britain: Collins.

Curran, J. (2009). Agatha Christie's Secret Notebooks. Fifty Years of Mysteries in the Making. UK. Harper Collins Publishers.

Demircan, A. (2003). Câhiliyye ve Hz. Peygamber Döneminde Çok Kadınla Evlilik. ISTEM. 1/2, 9-32.

Dixon, D. M. (2003). Some Egyptological Sidelights on the Egyptian War of 1882. In David Jeffreys (Ed.). Views of Ancient Egypt since Napoleon Bonaparte: Imperialism, Colonialism and Modern Appropriations. (pp. 87-94). London: Institute of Archeology.

Foucault, M. (2002). The Archeology of Knowledge. NY: Routledge.

Harris, J. G. (2010). Shakespeare and Literary Theory. USA: Oxford University Press, Inc.

Hassan, F. A. (2003). Imperialist Appropriations of Egyptian Obelisk. In David Jeffreys (Ed.). Views of Ancient Egypt since Napoleon Bonaparte: Imperialism, Colonialism and Modern Appropriations. (pp. 19-68). London: Institute of Archeology.

Hentsch, T. (1996). Hayali Doğu: Batı́nın Akdeniz'li Doğu'ya Politik Bakışı. (Aysel Bora, Trans.). İstanbul: Metis Yayıncılık Ltd.

Kelleghan, F. (Ed.). (2001). 100 Masters of Mystery and Detective Fiction. (Volume I). Pasadena, California: Salem Press, Inc. 
Leitch, V. B. et al. (Eds.) (2001). The Norton Anthology of Theory and Criticism. London: W. W. Norton and Company.

Loomba, A. (1998). Colonialism/Postcolonialism. Great Britain: Clays Ltd.

Osborne, C. (2001). Charles Osborne on Death on the Nile. Poirot 1937. In Agatha Christie. Death on the Nile. (pp. 449-454). Great Britain. Harper Collins Ltd.

Pennycook, A. (1998). English and the Discourses of Colonialism. London: Taylor and Francis Group.

Powell, E. M. T. (2003). A Different Shade of Colonialism: Egypt, Great Britain, and the Mastery of the Sudan. Berkeley: University of California Press.

Said, E. W. (1979). Orientalism. New York: Vintage Books.

Said, E. W. (1985) Orientalism Reconsidered. Cultural Critique. No. 1 (Autumn, 1985). 89-107, University of Minnesota Press.

Sarıçam, İ. et al. (2011). İngiliz ve Alman Oryantalistlerin Hz. Muhammed Tasavvuru. Ankara: Nobel Yayın Dağıım.

Tibawi, A. L. (2000). A Second Critique of English-Speaking Orientalists. In Alexander Lyon Macfie (Ed.), Orientalism: A Reader. (pp. 145-171). New York: New York UP.

Umunç, H. (2013). Doğu ve Ötekilik: İngiliz Seyahatnamelerinde Türk Kimliği (Lady Montagu ve Richard Chandler). Bilig, 66 (Yaz), 297-314.

Yıldız, H. D. et al. (1989). Doğuştan Günümüze Büyük İslam Tarihi. İstanbul: Çağ Yayınları.

Young, R. J. C. (1990). White Mythologies: Writing History and the West. London: Taylor \& Francis.

Veeser, H. Aram. (2010). Edward Said: The Charisma of Criticism. New York: Routledge.

\section{Internet Sources}

Bayle, P. (1826). Mohametanism. In An Historical and Critical Dictionary. (Vol. II., 246-264). London: Hunt \& Clark. Retrieved from https://archive.org/stream/anhistoricaland02baylgoog\#page/n8/mode/2up 
Western Image Of The Orient And Oriental In Agatha Christie's Death On The Nile: A Postcolonial Reading

Christie, A. (2015). Death on the Nile. Retrieved from https://kohledeyes.files.wordpress.com/2016/01/death-on-the-nile-by-agathachristie.pdf

dahabeeah/dahabeeyah/dahabiah. Retrieved from http://www.collinsdictionary.com/dictionary/english/dahabeah\#dahabeah 1

Tibawi, A. L. English-Speaking Orientalists: A Critique of Their Approach to Islam and Arab Nationalism. Retrieved from http://www.muslimlibrary.com/dl/books/English/English Speaking Orientalists.p df 